\title{
Contributions on enhancing the copper uptake by using natural chelators, with applications in soil phytoremediation
}

\author{
A. Dumbrava $\cdot$ S. Birghila $\cdot$ M. Munteanu
}

Received: 27 July 2013/Revised: 22 November 2013/Accepted: 7 December 2013/Published online: 8 January 2014

(C) Islamic Azad University (IAU) 2013

\begin{abstract}
The chelate assisted phytoremediation of polluted soils, based on the complexation of metals with chelators, can be a valuable green solution for agricultural soils decontamination. Copper is considered a hardly available and slowly translocating element, but the complexation may increase its bioavailability and translocation capacity, with benefits for soil phytoremediation. In our study, the ability of horse manure-a natural source of compounds which can act as chelators for enhancing the bioavailability and uptake of copper from contaminated soils-was investigated, by the use of white mustard ( $\mathrm{Si}$ napis alba) as the accumulator plant; the results were compared with those obtained for ethylenediaminetetraacetate, a synthetic chelator. The copper bioavailability, bioaccumulation, uptake, and thus the potential for phytoremediation of copper polluted soils, were estimated by translocation factor, bioaccumulation factor, and uptake coefficient. The results indicated that the use of horse manure as natural chelators source can improve the copper phytoextraction capacity, also having the advantage of an increase in biomass.
\end{abstract}

Keywords Copper bioavailability - Bioaccumulation factor - Translocation factor - Uptake factor .

Horse manure $\cdot$ Mustard

\footnotetext{
A. Dumbrava $(\bowtie) \cdot$ S. Birghila $\cdot$ M. Munteanu Department of Chemistry and Chemical Engineering, Ovidius University of Constanta, 900527 Constanta, Romania e-mail: adumbrava@univ-ovidius.ro

M. Munteanu

Sanitary Veterinary and Food Safety Authority of Constanta, 900111 Constanta, Romania
}

\section{Introduction}

The bioavailability of metals from soil is a very important issue in agricultural and environmental studies, being interesting both for understanding the processes involved in the metals uptake by plants and for finding the most reliable methods to predict the availability of a given element to plants, in particular to crop plants. The metals uptake is also important in the phytoremediation process, an emerging technology that employs the use of higher plants for the clean-up of contaminated environment (Kabata-Pendias 2004). For phytoremediation to be successfully, a strategy which combines rapid screening of plant species, possessing the ability to tolerate and accumulate toxic metals, with agronomic practices that enhance shoot biomass production and/or increase metal bioavailability in the rhizosphere should be considered (Salt et al. 1998; Rimmer et al. 2001; Dean 2007).

Salt et al. (1998) assumed that two basic strategies of phytoextraction may be formulated: chelate assisted phytoextraction (induced phytoextraction) and long-term continuous phytoextraction. The success of phytoremediation depends both on the choice of plant species and the metal forms retained in soils. Several options have been employed to facilitate phytoremediation, including the use of proper chelating agents to enhance metal mobility in soils and suitable vegetation to translocate metals from underground tissues to aerial parts of the plants (Yeh and Pan 2012). In fact, they are known four different plantbased technologies of phytoremediation, with different mechanisms of action, which are used for containment (i.e. phytoimmobilization and phytostabilization) or removal (i.e. phytoextraction and phytovolatilization) of contaminants from soils (Padmavathiamma and Li 2007).

Chelating agents have been shown to desorb metals from the soil matrix into the soil solution, and to facilitate metal 
translocation from roots to shoots, but their effect may differ depending on the plant or metal species. The chelators are frequently used to increase the bioavailability of heavy metals, thus enhancing their uptake by plants, although this may decrease their biomass because of the toxicity. Moreover, chelators can mobilize soil nutrients, since the fertilizing action of chelators has been reported (Yeh and Pan 2012). The copper complexation by chelating agents has many other applications in analytical and environmental chemistry (Mobin et al. 2010; Sanghavi et al. 2013).

Ethylenediaminetetraacetate (EDTA), probably the most efficient chelator in increasing the concentration of various metals in above-ground plant tissues, has a high efficiency relying on the solubilization of poorly available metals (e.g. lead, chromium, copper), followed by a largely passive accumulation of metal complexes in plant shoots through the transpiration stream. However, many authors reported that the slow degradation rate and long persistence of EDTA in soil (becoming a contaminant) increase the metal leaching risk and make it unsuitable for use under field conditions. (do Nascimento et al. 2006; Turgut et al. 2010; Wua et al. 2003) Thus, the use of natural compounds, as chelators in phytoremediation, seems to be more advantageous compared with synthetic ones (like EDTA).

The behaviour, phytobioavailability, and toxicity of copper (a hardly available and slowly translocating element) are influenced by several soil variables, such as dissolved organic matter, which has a great affinity to fix copper and thus to inhibit its sorption in soils. These phenomena are attributed to the formation of soluble $\mathrm{Cu}$-organic complexes (Máthé-Gáspár and Anton 2005). Basic research is still needed on the use of natural and synthetic chelating agents for the inducement of pollutants hyperaccumulation.

The purpose of our study was to estimate the influence of horse manure, which is frequently used as a fertilizer for soils, but which may also be a source of natural chelators, in the uptake of copper from contaminated soils, using the white mustard (Sinapis alba, family Brassicaceae, also referred to it as Brassica alba or B. Hirta) as accumulator plant. Mustards were identified as hyperaccumulators for Cd, Cs, Ni, Sr (McCutcheon and Schnoor 2003), and our preference for white mustard is justified by the fact that it was less studied in comparison with other mustard species, like Indian mustard. The previous results for phytoremediation using sheep manure do not have the expected success (Sinegani and Khalilikhah 2011), but our aim was to improve the method, to apply it in other systems and to find the proper metal-chelator-plant combination for successful phytoremediation. We have also compared the performance of naturally occurring compounds (from horse manure) with a synthetic chelator (EDTA) in enhancing phytoextraction of copper in an artificially contaminated soil.
The issue of metals extraction by phytoremediation from polluted soils, in the presence of horse manure, may be included in the global problem of environmental pollution reduction; some other decontamination techniques also using waste materials (Jain et al. 2003a, b; Mittal et al. 2008, 2009, 2010a, b; Gupta et al. 1997, 2007, 2011a, b).

\section{Materials and methods}

Materials

All the reagents were purchased from commercial sources and used as received. The white mustard seeds were also purchased from commercial sources.

Horse manure was produced on a farm in Constanta County, Romania, nearby the agricultural land from which was taken the soil. Horse manure extract (HME) was prepared by water extracting from fresh horse manure in the 1:5 ratio of manure to distilled water. The suspension was stirred for $30 \mathrm{~min}$ and then filtered. $120 \mathrm{~mL}$ of HME was obtained, starting from $150 \mathrm{~g}$ of horse manure. Horse manure extract has neutral-slightly alkaline $\mathrm{pH}$ (7.85). Copper concentration in $\mathrm{HME}$ was $0.05 \mathrm{mg} \mathrm{L}^{-1}$.

\section{Soil treatment and analysis}

The soil $(0-30 \mathrm{~cm})$ tested in our study was chernozem (also known as calcareous black soil, eluviated black soil, or mollisol), taken from Constanta County, Romania. We used for experiments soil samples (Table 1) consisting of untreated soil from agricultural land (chernozem, S1), respective treated soil, a mixture of chernozem, and compost, based on dried and aged horse manure (DHM), prepared for flowers and vegetables cultivation in green houses, in the year before experiments (S7).

Table 1 The soil samples used in experiments

\begin{tabular}{lll}
\hline Sample & $\begin{array}{l}\text { Artificial soil contamination } \\
\left(\mathrm{mg} \mathrm{Cu}^{\mathrm{III}} \mathrm{kg}^{-1} \text { d.w. }\right)\end{array}$ & Chelator \\
\hline S1 & - & - \\
S2 & 250 & - \\
S3 & & EDTA \\
& & $\left(0.5 \mathrm{~g} \mathrm{~kg}^{-1}\right.$ soil $)$ \\
S4 & EDTA \\
& & $\left(1.0 \mathrm{~g} \mathrm{~kg}^{-1}\right.$ soil $)$ \\
S5 & $\mathrm{HME}$ \\
& & $\left(40 \mathrm{~mL} \mathrm{~kg}^{-1}\right.$ soil $) ;$ \\
S6 & & DHM \\
S7 & - & DHM \\
\hline
\end{tabular}


The soil samples were dried indoors until they could be crumbled to pass through a 4-mm sieve for pots experiment and a $2-\mathrm{mm}$ sieve for analyses of properties.

The soil water content was determined by gravimetric method. The soil $\mathrm{pH}$ was determined using standard method for land, respective greenhouse soils (JICA 2003; Rimmer et al. 2001). The characteristics for original soils (electrical conductivity, carbonates, chlorides, calcium, magnesium, total organic matters) were determined for aqueous extracts using standard methods (Pansu and Gautheyrou 2006; USEPA 1995). A Consort 535 pH-meter, for pH determination, and a Consort K600 conductometer, for the determination of electrical conductivity, were used.

Soil was transferred to $20-\mathrm{cm}$ diameter plant pots $(3 \mathrm{~kg}$ of soil in each) and soil samples were treated with $250 \mathrm{mg} \mathrm{Cu}$ (II) $\mathrm{kg}^{-1}$ d.w. $\left(\mathrm{CuSO}_{4} \cdot 5 \mathrm{H}_{2} \mathrm{O}\right)$ as pollutant. The amounts of copper sulphate which must be added to achieve the target solution concentrations were calculated to be lower than half maximal effective concentration $\left(\mathrm{EC}_{50}\right)$ of copper, determined in other studies. For example, the $\mathrm{EC}_{50}$ values reported by Mitchell et al. (1988) for three native Australian species ranged from 205 to $610 \mathrm{mg} \mathrm{Cu} \mathrm{kg}^{-1}$, but the values strongly depends on the soil characteristics, plants species, and other factors. The copper sulphate was dissolved in deionized water into each pot and then saturated, air dried at room temperature and thoroughly mixed. The wetting-drying mixing process was repeated to ensure soil equilibrium for 1 month, under natural light (Turan and Esringü 2007).

After the incubation period, the copper contaminated soils were treated with EDTA solutions, at the rates of 0.5 and $1.0 \mathrm{mg}$ EDTA kg ${ }^{-1}$ soil, and with $40 \mathrm{~mL} \mathrm{HME} \mathrm{kg}{ }^{-1}$ soil. Concentrations of EDTA and HME were based on upper soil surface layer and were sprayed on the soil surface, following procedures described by Vogeler et al. (2001).

The soil total copper was extracted by a mixture of $\mathrm{HNO}_{3}, \mathrm{H}_{2} \mathrm{O}_{2}$, and $\mathrm{HCl}$ (USEPA 2000). The bioavailable copper fraction was extracted with a $\mathrm{CaCl}_{2}$ solution (Houba et al. 2000; Benton Jones 2001). All determination was made triplicate. The obtained solutions were prepared for copper determination.

\section{Plant growth experiments}

The seeds of $S$. alba were sterilized with a $\mathrm{HgCl}_{2} 0.1 \%$ solution, by vigorous shaking for $1 \mathrm{~min}$ and washed in abundance with deionized water. The sterilized seeds were germinated on Petri dishes (10 seeds dish $\left.{ }^{-1}\right)$, lined with filter paper and impregnated with $6 \mathrm{~mL}$ of distilled water. After the plants had grown for 14 days, three plants were selected, each with similar lengths (between 5 and $10 \mathrm{~cm}$ ), and a pot experiment was carried out under laboratory conditions (natural light, $25{ }^{\circ} \mathrm{C}$ temperature) (Branzini et al. 2012). All experiments were made triplicate, and the mean values were reported.

The plants were planted and grown into 6 soil samples, namely S1-S6.

After 30 days, the plants were harvested. Plant samples (roots and shoots) were separated and thoroughly rinsed in abundant deionised water after mechanical cleaning, dried at $70{ }^{\circ} \mathrm{C}$ until the stabilization of weight $(48 \mathrm{~h})$, and weighed. The obtained tissue samples were crushed and digested using a $\mathrm{H}_{2} \mathrm{O}_{2} / \mathrm{HNO}_{3}$ mixture $(10 / 8$, v/v) in a Digesdahl Digestion Apparatus, 230 Vac (Hach). The obtained solutions were prepared for copper determination.

Determination of $\mathrm{Cu}$ in plant and soil samples

The copper content in plants and soil samples was determined by the atomic absorption method (FAAS technique) on a GBC Avanta PM atomic absorption spectrometer (purchased from Romspectra Impex Ltd. Bucharest, Romania), equipped with air-acetylene flame, using an aqueous standard calibration curve. Analyses were made triplicate, and the mean values were reported. Acetylene of $99.99 \%$ purity at a flow rate $1.8-2.0 \mathrm{~L} \mathrm{~min}^{-1}$ was utilized as fuel gas and also as carrier gas for introducing aerosols. Concentrations of copper were measured using monoelement hollow cathode lamp. The characteristics of metal calibration curve are: wavelength $329.7 \mathrm{~nm}$, concentration range $0.100-1.000 \mathrm{mg} \mathrm{L}^{-1}$, and correlation coefficient 0.9990 (Skoog et al. 1996). Analyses were made triplicate, and the mean values are reported.

Validation of the method was performed with respect to linearity, limit of detection (LOD), limit of quantification (LOQ), accuracy and precision, in accordance with International Conference on Harmonisation (ICH) Guidelines (ICH Expert Working Group 2005).

\section{Method validation}

A linear trend between the absorbance and copper concentration was observed in the range of $0.1-1 \mathrm{mg} \mathrm{L}^{-1}$. The coefficient of determination $\left(r^{2}\right)$, obtained from regression line, was 1.000. The applied spectrometric method is based on a calibration curve for quantitative analysis, and the LOD and LOQ were determined using following equations: $\mathrm{LOD}=3 s / a ; \quad \mathrm{LQD}=10 s / a$, where $s$ is the standard deviation of replicate determination and $a$ is the sensitivity, namely the slope of the calibration graph (International Conference on Harmonisation 2005). The values of LOD and LOQ were 0.0027 and $0.009 \mathrm{mg} \mathrm{L}^{-1}$, respectively.

The accuracy of the method is presented in Table 2. A $0.5 \mathrm{mg} \mathrm{L}^{-1}$ standard solution was spiked with known amounts of standard solutions $(0.2,0.3,0.4$, and $0.6 \mathrm{mg} \mathrm{L}^{-1}$ ), and the measured values were compared with 
Table 2 The evaluation of precision and accuracy for the copper determination

\begin{tabular}{llll}
\hline $\begin{array}{l}\text { Amount added } \\
\left(\mathrm{mg} \mathrm{L}^{-1}\right)\end{array}$ & $\begin{array}{l}\text { Amount found } \\
\left(\mathrm{mg} \mathrm{L}^{-1}\right)^{\mathrm{a}}\end{array}$ & $\begin{array}{l}\text { Accuracy } \\
(\%)^{\mathrm{b}}\end{array}$ & $\begin{array}{l}\text { Precision } \\
(\mathrm{RSD})^{\mathrm{c}}\end{array}$ \\
\hline 0.20 & $0.184 \pm 0.20$ & $92.0 \pm 0.04$ & 0.67 \\
0.30 & $0.296 \pm 0.15$ & $98.6 \pm 0.12$ & 1.02 \\
0.40 & $0.380 \pm 0.29$ & $95.0 \pm 0.09$ & 2.79 \\
0.60 & $0.578 \pm 0.13$ & $96.3 \pm 0.34$ & 1.49 \\
\hline
\end{tabular}

${ }^{\text {a }}$ Values are means of three replications \pm standard deviation

b Accuracy (\%) is calculated as (obtained value/spiked value) $\times 100$

${ }^{c}$ Precision (repeatability), \%RSD = standard deviation of concentration measured/mean of concentration measured

the known added values. The results showed that the accuracy was in the range $92.0-98.6 \%$, and the spectrometric method applied for the determination of copper can be considered as an accurate method within the investigated concentration range.

The precision of the method, reported as relative standard deviation (RSD), was estimated by measuring repeatability of the measurement for three replicates at different concentrations $\left(0.2,0.3,0.4\right.$ and $\left.0.6 \mathrm{mg} \mathrm{L}^{-1}\right)$. The $\%$ of RSD values were less than $3 \%$, confirming a good precision of the method.

Recovery studies were carried out to determine the accuracy of the method. Samples were analysed before and after addition of known amounts of cooper solutions, and it was found that recoveries ranged between 90 and $98.6 \%$. The results confirmed that although the matrix composition was complex and presented different mineral content, it does not cause interference effects.

\section{Results and discussion}

\section{Copper concentration in soils}

In the first stage of our study, the influence of horse manure (in two forms, namely extract from fresh manure, respective dry and aged manure) on the copper bioavailability was tested. For comparison, the influence of EDTA was also tested.

The scientific studies (Moral et al. 2005) demonstrated that horse manure can be used as amendment in agricultural soils, to achieve both their disposal and the improvement of soil properties, due to their very high organic matter contents; but the organic matter stabilization process starts after application to soil, since only the manures which had undergone the beginning of the stabilization process, due to their greater storage time, showed values of the parameters related to organic matter maturity within or close to the established limits for mature organic materials. In our study, the idea that it is easier to manipulate and store an aqueous extract of manure, compared to the solid manure was assumed. Moreover, the extract is made from fresh manure, which is expected to contain more organic matter compared to aged horse manure, and the organic compounds can act as chelating agents. Another argument for water extract versus a solid material is that the water soluble components of solid chelators can be washed out by rain when it is spread on a filed.

A characterization of original land soil (S1) and treated soil (land soil and compost, S7) is presented in Table 3. As expected, the experimental data revealed a higher concentration of organic matter in treated soil. Moreover, the electrical conductivity and concentration of some components (calcium, magnesium, chlorides, carbonates) showed a high concentration of inorganic compounds in S7 sample. This fact is important because the anions can also act as ligands for metals.

The original soils applied in this study contain $22.41 \mathrm{mg} \mathrm{Cu}$ (II) $\mathrm{kg}^{-1}$ d.w., $\quad$ respective $22.66 \mathrm{mg} \mathrm{Cu}$ (II) $\mathrm{kg}^{-1}$ d.w. (see Table 3). It is recognized that the average copper concentration in soils is $30 \mathrm{mg} \mathrm{kg}^{-1} \mathrm{~d}$.w. and the common range for soils is $2-100 \mathrm{mg} \mathrm{kg}^{-1}$ d.w. (McLean and Bledsoe 1992; Kabata-Pendias and Mukherjee 2007); thus, the studied soils may be considered as uncontaminated soils prior to spiking with copper sulphate as pollutant. The artificial contamination with copper aims to mimic the soil pollution in vineyards $\left(100-1,500 \mathrm{mg} \mathrm{kg}^{-1}\right)$, near copper facilities (70-1,600 $\mathrm{mg} \mathrm{kg}^{-1}$ ), mine dump (273-5,241 $\mathrm{mg} \mathrm{kg}^{-1}$ ), etc. (Kabata-Pendias and Mukherjee 2007). The values for total copper concentration, both determined and resulted from calculation, are plotted in Fig. 1.

The bioavailable (mobile) copper fraction in soil was considered to be the fraction that is not tightly bound to soil (Benton Jones 2001; Dean 2007). The bioavailable (exchangeable) copper concentration in soil samples was determined because several studies indicated a correlation between the soluble metal concentration in soil and metal concentration in plants (Zehra et al. 2009). The results are presented in Fig. 1.

Table 3 The physical and chemical characteristics for the original land soil (S1) and the DHM treated soil (S7)

\begin{tabular}{|c|c|c|}
\hline Parameters & $\mathrm{S} 1$ & S7 \\
\hline $\mathrm{pH}_{\text {water }}$ & 7.90 & 7.67 \\
\hline Electrical conductivity water $_{\left(\mathrm{dS} \mathrm{m}^{-1}\right)}$ & 0.31 & 0.57 \\
\hline Carbonates ( $\mathrm{g} \mathrm{kg}^{-1}$ d.w.) & 1.97 & 5.20 \\
\hline Chlorides ( $\mathrm{g} \mathrm{kg}^{-1}$ d.w.) & 0.33 & 2.96 \\
\hline Calcium (mg kg ${ }^{-1}$ d.w.) & 65.60 & 700.00 \\
\hline Magnesium (mg kg ${ }^{-1}$ d.w.) & 0.04 & 0.46 \\
\hline Total organic matters $\left(\mathrm{g} \mathrm{O}_{2} \mathrm{~kg}^{-1}\right.$ d.w. $)$ & 0.12 & 5.81 \\
\hline Copper (mg kg ${ }^{-1}$ d.w.) & 22.41 & 22.66 \\
\hline
\end{tabular}




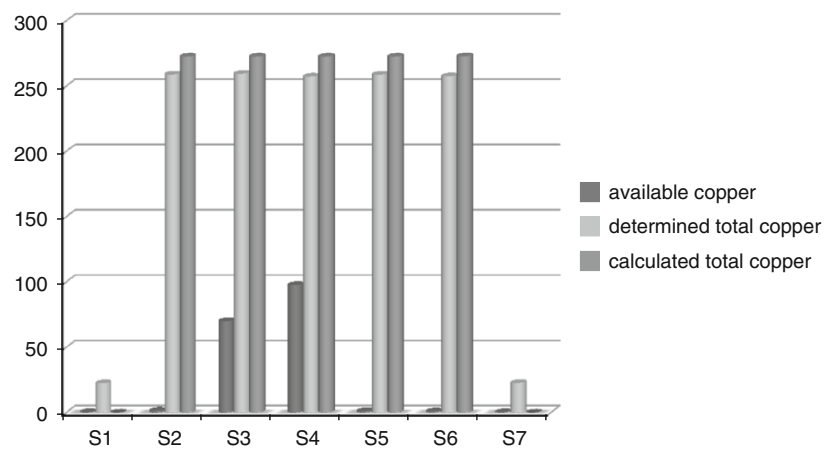

Fig. 1 The bioavailable fraction and total concentration of copper in soil samples ( $\mathrm{mg} \mathrm{kg}^{-1}$ d.w.)

From Fig. 1 we can conclude the following:

- a good correlation between the calculated and determined values of the total copper concentration may be observed. The determined values are around of $95 \%$ of calculated ones;

- in absence of a chelator, the fraction of bioavailable copper reported to total copper is very low, meaning that the added copper is not in a bioavailable form. The adding of EDTA increases the fraction of bioavailable copper, and we can make a correlation between EDTA content and copper bioavailable fraction. On the contrary, the horse manure did not increase the fraction of bioavailable copper in soils, meaning that it did not convert the added copper in a bioavailable form, in terms of extraction with $\mathrm{CaCl}_{2}$ solution;

- in soil samples treated with horse manure, the copper bioavailability is very similar $\left(0.99 \mathrm{mg} \mathrm{kg}^{-1}\right.$ d.w. in S5, $0.80 \mathrm{mg} \mathrm{kg}^{-1}$ d.w. in S6 samples) and comparable with the value determined for untreated sample S2 $\left(1.26 \mathrm{mg} \mathrm{kg}^{-1}\right.$ d.w.), thus, the amendment of soil does not seem to increase the copper bioavailability. Furthermore, the procedure of manure application to soil does not affect the copper bioavailability, determined as above;

- it is known that the retention of metals in soil depends on the $\mathrm{pH}$ value (McLean and Bledsoe 1992). In our study, the values of $\mathrm{pH}$ of are nearly the same (S1 7.90; S2 7.83; S3 7.79; S4 7.84; S5 7.79; S6 7.88; S7 7.67), meaning around $7.80-7.90$, for all soil samples. This means that the $\mathrm{pH}$ value can not be used as a criterion for a comparison between soil samples.

Sauvé et al. established an empirical relationship for copper content, based on the analysis of a wide variety of urban, agricultural, and forest soils:

Soluble $\mathrm{Cu}=0.32$ total $\mathrm{Cu}+13.2$

where soluble $\mathrm{Cu}$ is in $\mu \mathrm{g} \mathrm{L}^{-1}$ in the $0.01 \mathrm{M} \mathrm{CaCl}_{2}$ extracts and total $\mathrm{Cu}\left(\mathrm{HNO}_{3}\right.$ digestion) is in $\mathrm{mg} \mathrm{kg}^{-1}$ of dry soil (Rimmer et al. 2001).
A comparison between experimental and calculated values for soluble copper is presented in Table 4. It can be seen that, for the samples which were not treated with EDTA, the calculated values for soluble copper are in good agreement with the determined ones. The addition of EDTA in soil samples results in a growth of soluble copper concentration, while the empirical equation has no relevance. On the contrary, the application of horse manure, in both forms, does not increase the soluble copper concentration, and the values of soluble and total copper can be fitted in the equation, as for an untreated soil.

Despite the high trend of retention of copper as precipitates in soil, copper has a high affinity for soluble organic ligands and the formation of these complexes may greatly increase its mobility in soils. The extent of complexation between a metal and the soluble organic matter depends on the competition between the metal-binding surface sites and the soluble organic ligand for the metal (McLean and Bledsoe 1992). This trend is very well illustrated by the results obtained in EDTA treated soil samples, but is unpredictable in the case of horse manure treatment. In our opinion, there may be two possibilities, i.e. the horse manure does not contain proper ligands for obtaining soluble and stable copper complexes or the organic components of horse manure interact with copper, but the products are not soluble. Anyway, the $\mathrm{pH}$ values for neutral soil and HME are favourable for metal-ligand interactions, feature which leads us to the supposition that a reaction between metals and organic compounds is, however, possible. These results, which are apparently surprising for copper chemistry, were recently confirmed by studies involving the use of manure amendments. Thus, Pérez-Esteban et al. $(2011,2012)$ communicated that the addition of the manure compost significantly reduced the metal bioavailability and redistributed the metals from the most labile fraction to the most stable fractions.

\section{Copper concentrations in plants}

Copper contents in plants vary greatly and are controlled by several factors, in which the pool of mobile copper in soils and plant properties play significant roles. Despite general copper tolerance in plants, this metal is considered to be quite toxic. The effects of copper excess, such as decrease of photosynthesis and yield, are well known. The most common characteristic symptoms of the copper and copper toxicity are: (1) root malformation, (2) damage to membrane permeability, (3) inhibition of photosynthetic electron transport, (4) damage to DNA, and (5) immobilization of copper in membranes and protein complexes (Kabata-Pendias and Mukherjee 2007).

Zehra et al. (2009) reported that application of EDTA on heavy metal contaminated soils significantly decreased root and shoot dry matter yields of some plants; the decrease 
Table 4 The calculated and determined concentration of soluble copper in the soil samples

\begin{tabular}{|c|c|c|c|c|c|}
\hline Sample soil & $\begin{array}{l}\text { Total copper } \\
\text { concentration } \\
\text { (mg kg }{ }^{-1} \text { d.w.) }\end{array}$ & $\%$ RSD & $\begin{array}{l}\text { Determined soluble } \\
\text { copper concentration } \\
\left(\mu \mathrm{g} \mathrm{L}^{-1}\right)\end{array}$ & $\%$ RSD & $\begin{array}{l}\text { Calculated soluble } \\
\text { copper concentration } \\
\left(\mu \mathrm{g} \mathrm{L}^{-1}\right)\end{array}$ \\
\hline $\mathrm{S} 1$ & 22.41 & 3.19 & 32 & 13.87 & 20.37 \\
\hline $\mathrm{S} 2$ & 258.83 & 7.38 & 126 & 3.32 & 96.03 \\
\hline $\mathrm{S} 3$ & 259.42 & 7.64 & 6,980 & 1.38 & 96.21 \\
\hline $\mathrm{S} 4$ & 257.21 & 8.21 & 9,760 & 0.99 & 95.51 \\
\hline S5 & 258.73 & 7.98 & 99 & 8.79 & 95.99 \\
\hline S6 & 257.41 & 8.14 & 80 & 9.21 & 95.57 \\
\hline S7 & 22.66 & 2.31 & 25 & High & 20.45 \\
\hline
\end{tabular}

Table 5 The copper concentration ( $\mathrm{mg} \mathrm{kg}^{-1}$ dry weight) in roots, stems and leaves

\begin{tabular}{|c|c|c|c|c|c|c|c|}
\hline \multirow[t]{2}{*}{ Sample } & \multirow[t]{2}{*}{ Chelator } & \multicolumn{6}{|c|}{ Copper concentration ( $\mathrm{mg} \mathrm{kg}^{-1}$ d.w.) } \\
\hline & & Roots & $\%$ RSD & Stems & $\% \mathrm{RSD}$ & Leaves & $\%$ RSD \\
\hline $\mathrm{S} 1$ & - & 28.59 & 7.85 & 19.5 & 9.53 & 42.57 & 0.59 \\
\hline $\mathrm{S} 2$ & - & 153.06 & 2.50 & 405.72 & 1.71 & $2,585.54$ & 12.28 \\
\hline S3 & EDTA $\left(0.5 \mathrm{~g} \mathrm{~kg}^{-1}\right.$ d.s. $)$ & 298.50 & 8.32 & 701.73 & 2.99 & $2,967.00$ & 15.79 \\
\hline S4 & EDTA $\left(1 \mathrm{~g} \mathrm{~kg}^{-1}\right.$ d.s. $)$ & 229.90 & 3.96 & $2,614.20$ & 2.63 & $1,943.29$ & 9.68 \\
\hline S5 & HME & $1,042.37$ & 6.89 & 39.96 & 2.23 & 51.37 & 1.01 \\
\hline S6 & DHM & 82.47 & 0.72 & $1,890.43$ & 9.51 & 144.57 & 0.18 \\
\hline
\end{tabular}

being considerable when EDTA addition levels were higher than $3 \mathrm{mmol} \mathrm{kg}^{-1}\left(1,000 \mathrm{mg} \mathrm{kg}^{-1}\right)$. Starting from this observation, in our study, we did not exceed this concentration, and the total mass of plants was roughly constant for the experiments involving S3 and S4 compared to S1 and S2. The same observation was done for S5 experiment, but for S6 the mass of plants was significantly higher, namely the highest of all experiments (3.66 g dry shoots compared to $1.20 \mathrm{~g}$ for $\mathrm{S} 2$ ).

The concentration of copper in roots, stems, and leaves are listed in Table 5. According to Ross (1994), the copper concentrations in polluted plants are between 20 and $100 \mathrm{mg} \mathrm{kg}^{-1}$. In our study, all samples of plants had very high contents of $\mathrm{Cu}$, even in the absence of a chelator, but the results are in concordance with other studies; e.g. $708.4 \mathrm{mg} \mathrm{kg}^{-1}$ in a wild plant, $P$. avium L., Rosaceae, in absence of a chelator (Maric et al. 2012). Although all these concentrations have extremely been high, they are still much lower than the ones in Ipomoea alpina, which is the best known hyperaccumulator of $\mathrm{Cu}$, and which can accumulate $12,300 \mathrm{mg} \mathrm{kg}^{-1}$ of $\mathrm{Cu}$ in its shoots (Cunningham and Ow 1996; Maric et al. 2012).

Starting from the experimental data given in Table 5, the following considerations can be formulated:

- the quantity of copper transferred from soil to plant was too high, and in these conditions, it was expected leaves to be affected by chlorosis, which in fact was observed;

- the highest copper concentration was found in the shoots harvested from $\mathrm{S} 4$, the soil with maximum EDTA concentration, which reveals the capacity of EDTA to mobilized the copper from soil to plant. However, for the S3 and S4 experiments, the vegetable mass $(0.95 \mathrm{~g} \mathrm{~d} . \mathrm{w}$. of shoots, respective $0.60 \mathrm{~g})$ was lower compared with $\mathrm{S} 2$ experiment (1.20 g d.w. shoots). This observation may have at least two explanations:

1. a high concentration of EDTA in soil involves a high bioavailability of copper (and other metals) and thus a high concentration in plants. In these conditions, the copper may be toxic for the plant, consequently the chlorosis was observed and the vegetal mass was decreased;

2. the EDTA in high concentration may itself be toxic for the plants, as other researchers observed (Yeh and Pan 2012). In our opinion, the toxicity of EDTA is also due to its ability to act as a hexadentate ligand, leading to the complexation of metals in soil solution and facilitating the transfer to plants. The metals concentration in plant becomes higher, and the toxicity of EDTA acts not only by itself, but also through toxic metals as well; 
- the concentration of copper in plants harvested from S5 is the lowest, but it is interesting that the concentration in roots is the highest, much higher than in S3 and S4 experiments. This behaviour may have a practical application because the shoots of plants grown in such conditions are not contaminated with copper and can still be used, while the roots have accumulated high cooper concentration and can be removed.

Phytoaccumulation and translocation of copper

The white mustard's potential for phytoextraction was assessed using some factors (bioaccumulation factor, translocation factor, uptake coefficient) as measures for its ability to uptake and translocate copper, in experimental conditions.

The transfer factor (TF) from soil to plant was definite by Freytag (1986) as the ratio between the metal content in plant (in $\mathrm{mg} \mathrm{kg}^{-1}$ plant d.w.) and the metal content in soil ( $\mathrm{mg} \mathrm{kg}^{-1}$ d.w.). The transfer of metal ions from the roots to the shoots is discussed in terms of translocation factor (TF), as the ratio of total metal concentration in the plants shoot to that in the roots (Ahlawat Sainger et al. 2011; Branzini et al. 2012).

The metal accumulation of plant species may be estimated by the bioconcentration factor (BCF) defined as ratio of the concentration metals in plant tissues (the aerial part of the plant) to the initial concentration in the environment (Zehra et al. 2009; Branzini et al. 2012).

Bioaccumulation is the process of taking up a chemical by an organism, either from direct exposure to a contaminated medium or by consumption of contaminated food (Schumacher et al. 1995). The bioaccumulation factor (BAF) was defined as the ratio of total metal concentration in shoots to concentration in soil, which is a measure of the ability of a plant uptake and transport metals to the shoots (Ahlawat Sainger et al. 2011).

The BAF, as defined above, may be understood as a transfer factor from soil to shoots or as the bioconcentration factor (ratio) in shoots. In some papers, the BCF and $\mathrm{BAF}$ have the same significance, meaning the ratio of shoot concentration to soil concentration (Wei et al. 2012); we used in this study the BAF expression.

It shall be deemed that plant species exhibiting TF and BAF greater than one are suitable for phytoextraction (Ahlawat Sainger et al. 2011).

Baltrénaité et al. (2012) proposed the use of dynamic factors to assess metal uptake and transfer in plants. Between the advantages of the proposed factors is the elimination of systematic errors of analysis and thus the improvement of precision and quality of evaluation.

The values of $\mathrm{BAF}, \mathrm{BAF}_{\mathrm{dyn}}$ (dynamic factor of metal bioaccumulation), $\mathrm{TF}$, and $\mathrm{TF}_{\mathrm{dyn}}$ (dynamic factor of metal translocation) for all experiments are plotted in Fig. 2.

From the data presented in Fig. 2, some remarks can be made:

- the considered factors are increasing with the copper concentration, even in the absence of a chelator, meaning that white mustard is a good accumulator for copper. The presence of EDTA in soil involves higher values for $\mathrm{BAF}$ and $\mathrm{BAF}_{\mathrm{dyn}}$, the growth being dependent of EDTA concentration. The variation of TF has the same trend, but less regular compared with BAF. Furthermore, the presence of EDTA in low concentration does not seem to favour the transfer of copper from roots to shoots;

- in the S5 experiment (HME as chelators source), the BAF is the lowest, much smaller in comparison with the other values, which means that HME prevents the accumulation of copper in aerial parts of the plants. Despite the fact that copper is easy absorbed by the roots and the copper concentration in roots is very high, the plants do not have the capacity to transfer cooper in the aerial part, probably because of the stability or low solubility of the complexes, formed by copper with accessible ligands from soil;

- in the S6 experiment, the BAF value is lower, compared with $\mathrm{S} 2$, meaning that the accumulation of copper is not favoured by the soil treatment, but the difference is small;

- the most obvious observation that can be made by looking to data from the graph is about high values of TF for the S6 experiment, meaning that white mustard harvested on treated soil has a high capacity to transfer copper in the aerial parts, the concentration in roots being small, comparable with the concentration determined in roots for the control experiment (S1), and this situation is just the opposite of the S5 experiment.

By comparing the $\mathrm{BAF}$ and $\mathrm{TF}$ to copper bioavailability, evaluated using a $\mathrm{CaCl}_{2}$ solution for extraction from soil, the following remarks result:

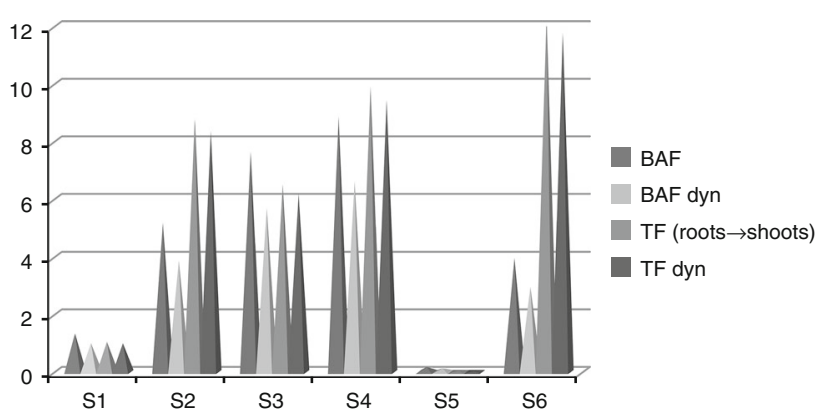

Fig. 2 The BAFs, $\mathrm{BAF}_{\mathrm{dyn}} \mathrm{s}, \mathrm{TFs}, \mathrm{TF}_{\mathrm{dyn}} \mathrm{s}$ calculated for $S$. alba grown on $\mathrm{S} 1-\mathrm{S} 6$ soils 
- the increasing of BAF and TF with the concentration of EDTA is consistent with the higher values for bioavailable copper concentrations estimated in presence of EDTA;

- the values of bioavailable copper concentrations in S5 and S6 could not provide the high concentration of copper accumulated by plants, either in roots (S5) or in shoots (S6). An explanation may be the presence of copper in insoluble and very stable complexes, from which it cannot be extracted by $\mathrm{CaCl}_{2}$ solution, but in natural systems, the plants have the mechanism to mobilize it. We can assume that, in such systems, the methods for estimation of copper bioavailability must be carefully applied.

Besides the TF which implies the translocation of copper from roots to the aerial parts of the plant, they can be calculated other TFs, involving the translocation of copper from different parts of the plants. Some variants for TFs are plotted in Fig. 3.

The data presented in Fig. 3 show a great concentration in shoots for S5 experiment and an easiest transfer from roots to stem for S6. The highest TF values are obtained for roots to stem transfer, copper being predominant retained in stems in the presence of a chelator as EDTA or natural chelators from DHM. In the absence of a chelator (S2), copper is consistently transferred from roots to stem and then to leaves; the highest copper concentration being in leaves. The presence of chelators may change the distribution and transfer of copper in plants.

The United States Environmental Protection Agency (USEPA 1992) introduces a metals takeover coefficient by plants, noted as uptake coefficient (UC), which expresses the amount of a metal taken up by a plant compared with the amount applied to the soil. This factor is obtained from the ratio between the amount of metals accumulated in some tissues of plants grown on land or fields, under varying degrees of impact with polluting material against the same plant species grown on unpolluted blank soil (Silveira et al. 2003).

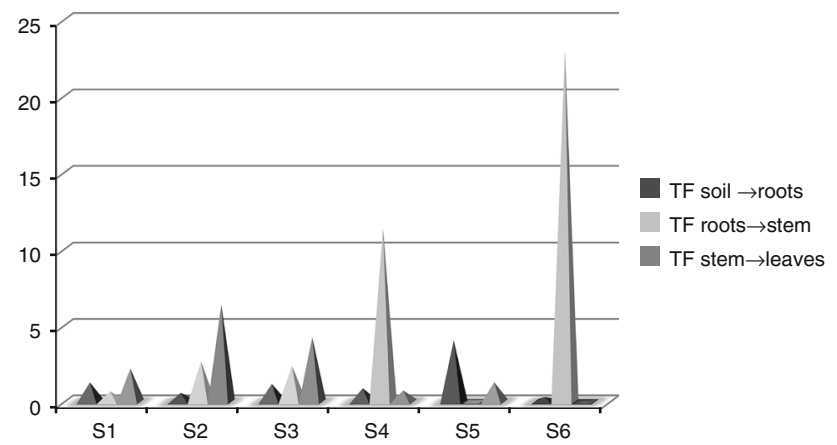

Fig. 3 The translocation factors calculated for $S$. alba grown on S1S6 soils
Taking into consideration the values UC (Table 6), we can make the following remarks:

- the capacity of white mustard to remove copper from soil, estimated by UC, has a significant value, even in the absence of a chelator, which demonstrates that it can be used for phytoremediation;

- the application of HME as a potential chelator source (S5) leads to a copper concentration around those obtained for plants grown on unpolluted soil, which is lower than those obtained in the absence of a chelator, meaning that the utilization of HME has blocked the transfer of copper from soil to shoots;

- the UC for S6 experiment has a value which is similar to those obtained for the soil untreated with chelator (S2), meaning that the DHM does not increased the capacity of plant to uptake copper and to transfer it to shoots. The advantage of using this soil consists in the quality of harvested plants, which have not chlorosis and, despite the medium value for UC, the removed copper quantity is higher because of a bigger vegetal mass.

The presence of organic matter as compost applied to polluted soil resulted in the mobilization of copper and a greater transfer compared to the case of unfertilization. Plants grown in the manure compost (containing DHM) treatments managed a greater amount of metals from the soil, accumulating them in their above-ground tissues due to the plants' higher growth. The application of this amendment could be a useful practice to remove copper from polluted soils by phytoremediation techniques. A similar remark was recently reported for other plants and metals (Pérez-Esteban et al. 2011, 2012).

The HME and DHM have a similar effect for the copper bioavailability, but HME has not the same nutritive effect as the DHM amendment, used as compost, probably because only a part of nutritive compounds are soluble in water, or because of the stage of nutrients biodegradation. As a consequence, the use of HME does not have the same effects as the use of DHM in the phytoremediation process. Furthermore, the two forms of horse manure application involve two technologies of phytoremediation: for HME, there is a phytostabilization (complexation mechanism),

Table 6 The values of uptake coefficient

\begin{tabular}{lrl}
\hline Experiment & $\begin{array}{l}\text { Copper concentration in shoots } \\
\left(\mathrm{mg} \mathrm{kg}^{-1} \text { d.w. }\right.\end{array}$ & $\begin{array}{l}\text { Uptake } \\
\text { coefficient }\end{array}$ \\
\hline S1 & 30.04 & - \\
S2 & $1,344.52$ & 44.76 \\
S3 & $1,944.85$ & 64.74 \\
S4 & $2,280.99$ & 75.93 \\
S5 & 46.74 & 1.56 \\
S6 & $1,021.83$ & 34.02 \\
\hline
\end{tabular}


meaning that the plants stabilize, rather than remove contaminants by plant roots metal retention, and for DHM, there is a phytoextraction (hyperaccumulation mechanism), meaning that the plants absorb copper from soil and translocate it to harvestable shoots, where they accumulate.

The white mustard grown in the treated soil fulfils the requirements for a successful phytoextraction, meaning that it has the ability to rapidly accumulate large quantities of biomass and the capacity to accumulate large quantities of environmentally important metals in the shoot tissue. It may be considered also a copper hyperaccumulator, having a metal accumulation exceeding a threshold value of shoot metal concentration of $0.1 \%$, which is request for copper accumulation (Padmavathiamma and $\mathrm{Li}$ 2007).

The use of EDTA as chelator involves high concentrations of copper in plants harvested from polluted soils, but the biomass is smaller. An explanation for the immobilization of copper in roots by HME may be correlated with copper compounds solubility, due to the nature of compounds which can act as ligands in HME, compared with DHM. The organic compounds are expected to be in a more advanced stage of degradation in dry manure than in the fresh manure that meaning smaller molecules with smaller molecular masses. A low molecular mass and an electric charge of complex involve a higher solubility, while complexes with high masses, possibly with polymetallic structures or uncharged, involve low solubility in water. Another explanation may be correlated with complexes stability, nature of donor atoms, coordination numbers, the synergism of ligands, but such explanations need complex information about the chemical composition of manure.

\section{Conclusion}

The main aim of our study was to estimate the ability of horse manure, chosen as a natural source of chelators, and enhance the copper accumulation in plants. It has been observed that the studied accumulator plant, white mustard, accumulated high copper concentrations in roots in the presence of HME, but it did not have the capacity to transfer copper in aerial parts; thus, the most probable phytoremediation mechanism was the phytostabilization. Plants harvested on soils treated with compost, containing DHM had a higher capacity for transferring copper from roots to shoots, even higher that for EDTA, thus the most probable phytoremediation mechanism was the phytoextraction. Furthermore, the mass of plants harvested on DHM treated soil was bigger and, consequently, the total quantity of removed copper was higher.

The phytoremediation capacity of the white mustard was demonstrated for soils with high copper concentration. The conclusion was that the white mustard had the capacity to accumulate copper from polluted soils, the bioaccumulation of copper being improved by the presence of a chelator, and the chelate assisted phytoextraction seems to be a good strategy for copper extraction.

Another observation was that, for studied polluted soils, the use of BAF, TF, and UC may be a good method to estimate the capacity of phytoremediation for a plant and also the bioavailability of copper, but the assessment of the copper bioavailability in polluted soils, using the method of extraction, has many limitations.

Acknowledgments The authors thank Mr. Constantin Ancuta (agricultural engineer) and his co-workers for supplying us the soil samples and for their kind assistance.

\section{References}

Ahlawat Sainger P, Dhankhar R, Sainger M, Kaushik A, Singh RP (2011) Assessment of heavy metal tolerance in native plant species from soils contaminated with electroplating effluent. Ecotoxicol Environ Saf 74:2284-2291

Baltrénaité E, Lietuvninkas A, Baltrénas P (2012) Use of dynamic factors to assess metal uptake and transfer in plants-example of trees. Water Air Soil Pollut 223:4297-4306

Benton Jones J Jr (2001) Laboratory guide for conducting soil tests and plant analysis. CRC Press, Boca Raton, FL

Branzini A, Santos González R, Zubillaga M (2012) Absorption and translocation of copper, zinc and chromium by Sesbania virgata. J Environ Manage 102:50-54

Cunningham SD, Ow DW (1996) Promises and prospects of phytoremediation. Plant Physiol 110:715-719

Dean JR (2007) Bioavailability, bioaccessibility and mobility of environmental contaminants. Wiley, Chichester

do Nascimento CWA, Amarasiriwardena D, Xin B (2006) Comparison of natural organic acids and synthetic chelates at enhancing phytoextraction of metals from a multi-metal contaminated soil. Environ Pollut 140:114-123

Freytag J (1986) Bestimmung von Trsansferfaktoren Boden/Pflanze einger Elemente und Untersuchungen uber deren Abhangigkeit von ausgewahlten Bodeneigenschaften. Hamburger Bodenkundliche Arbeiten 1:43-51

Gupta VK, Srivastava SK, Mohan D, Sharma S (1997) Design parameters for fixed bed reactors of activated carbon developed from fertilizer waste for the removal of some heavy metal ions. Waste Manage 17:517-522

Gupta VK, Ali I, Saini VK (2007) Defluoridation of wastewaters using waste carbon slurry. Water Res 41:3307-3316. doi:10. 1016/j.watres.2007.04.029

Gupta VK, Agarwal S, Saleh TA (2011a) Synthesis and characterization of alumina-coated carbon nanotubes and their application for lead removal. J Hazard Mater 185:17-23. doi:10.1016/j. jhazmat.2010.08.053

Gupta VK, Agarwal S, Saleh TA (2011b) Chromium removal by combining the magnetic properties of iron oxide with adsorption properties of carbon nanotubes. Water Res 45:2207-2212. doi:10.1016/j.watres.2011.01.012

Houba VJG, Temminghoff EJM, Gaikhorst GA, van Vark W (2000) Soil analysis procedures using $0.01 \mathrm{M}$ calcium chloride as extraction reagent. Commun Soil Sci Plant Anal 31:1299-1396

ICH Expert Working Group (2005) Harmonised tripartite guidelinevalidation of analytical procedures: text and methodology Q2(R1) 
Jain AK, Gupta VK, Bhatnagar A, Suhas (2003a) A comparative study of adsorbents prepared from industrial wastes for removal of dyes. Sep Sci Technol 38:463-481. doi:10.1081/SS-120016585

Jain AK, Gupta VK, Bhatnagar A, Jain S (2003b) A comparative assessment of adsorbents prepared from industrial wastes for the removal of cationic dye. J Indian Chem Soc 80:267-270

JICA, APM, Industrial Chemistry Faculty (2003) The control of soil quality. Cartea Universitara Publishing House, Bucuresti (in Romanian)

Kabata-Pendias A (2004) Soil-plant transfer of trace elements-an environmental issue. Geoderma 122:143-149

Kabata-Pendias A, Mukherjee AB (2007) Trace elements from soil to human. Springer, Berlin

Maric M, Antonijevic M, Alagic S (2012) The investigation of the possibility for using some wild and cultivated plants as hyperaccumulators of heavy metals from contaminated soil. Environ Sci Pollut Res. doi:10.1007/s11356-012-1007-9

Máthé-Gáspár G, Anton A (2005) Phytoremediation study: factors influencing heavy metal uptake of plants. Acta Biol Szeged 49:69-70

McCutcheon SC, Schnoor JL (2003) Overview of phytotransformation and control of wastes. In: McCutcheon SC, Schnoor JL (eds) Phytoremediation. Wiley, New Jersey, pp 3-58

McLean JE, Bledsoe BE (1992) Behavior of metals in soils, EPA/540/ S-92/018 ground water issue

Mitchell RL, Burchett MD, Pulkownik A, McCluskey L (1988) Effects of environmentally hazardous chemicals on the emergence and early growth of selected Australian native plants. Plant Soil 112:195-199

Mittal A, Gupta VK, Malviya A, Mittal J (2008) Process development for the batch and bulk removal and recovery of a hazardous, water-soluble azo dye (Metanil Yellow) by adsorption over waste materials (Bottom Ash and De-Oiled Soya). J Hazard Mater 151:821-832. doi:10.1016/j.jhazmat.2007.06.059

Mittal A, Kaur D, Malviya A, Mittal J, Gupta VK (2009) Adsorption studies on the removal of coloring agent phenol red from wastewater using waste materials as adsorbents. J Colloid Interface Sci 337:345-354. doi:10.1016/j.jcis.2009.05.016

Mittal A, Mittal J, Malviya A, Kaur D, Gupta VK (2010a) Decoloration treatment of a hazardous triarylmethane dye, Light Green SF (Yellowish) by waste material adsorbents. J Colloid Interface Sci 342:518-527. doi:10.1016/j.jcis.2009.10.046

Mittal A, Mittal J, Malviya A, Gupta VK (2010b) Removal and recovery of Chrysoidine $\mathrm{Y}$ from aqueous solutions by waste materials. J Colloid Interface Sci 344:497-507. doi:10.1016/j. jcis.2010.01.007

Mobin SM, Sanghavi BJ, Srivastava AK, Mathur P, Lahiri GK (2010) Biomimetic sensor for certain phenols employing a copper(II) complex. Anal Chem 82:5983-5992. doi:10.1021/ac1004037

Moral R, Moreno-Caselles J, Perez-Murcia MD, Perez-Espinosa A, Rufete B, Paredes C (2005) Characterisation of the organic matter pool in manures. Bioresour Technol 96:153-158

Padmavathiamma PK, Li LY (2007) Phytoremediation technology: hyper-accumulation metals in plants. Water Air Soil Pollut 184:105-126. doi:10.1007/s11270-007-9401-5

Pansu M, Gautheyrou J (2006) Handbook of soil analysis. Mineralogical, organic and inorganic methods. Springer, Berlin

Pérez-Esteban J, Escolástico C, Ruiz-Fernández J, Masaguer A, Moliner A (2011) Bioavailability and extraction of heavy metals from contaminated soil by Atriplex halimus. Environ Exp Bot. doi:10.1016/j.envexpbot.2011.12.003

Pérez-Esteban J, Escolástico C, Masaguer A, Moliner A (2012) Effects of sheep and horse manure and pine bark amendments on metal distribution and chemical properties of contaminated mine soils. Eur J Soil Sci. doi:10.1111/j.1365-2389.2012.01468.x
Rimmer DL, Reichman SM, Menzies NW (2001) Bioavailability of $\mathrm{Cu}, \mathrm{Zn}$, and $\mathrm{Mn}$ in contaminated soils and speciation in soil solution. In: Iskandar IK, Kirkham MB (eds) Trace elements in soil: bioavailability, flux, and transfer. Lewis Publishers, CRC Press, New York, pp 77-88

Ross MS (1994) Sources and form of potentially toxic metals in soil plant systems. In: Ross MS (ed) Toxic metals in soil plant systems. Wiley, Chichester, pp 3-25

Salt DE, Smith RD, Raskin I (1998) Phytoremediation. Annu Rev Plant Physiol Plant Mol Biol 49:643-668

Sanghavi BJ, Mobin SM, Mathur P, Lahiri GK, Srivastava AK (2013) Biomimetic sensor for certain catecholamines employing copper(II) complex and silver nanoparticle modified glassy carbon paste electrode. Biosens Bioelectron 39:124-132. doi:10.1016/j. bios.2012.07.008

Schumacher BA, Neary AJ, Palmer CJ, Pastorek L, Morrison IK, Marsh M (1995) Laboratory methods for soil and foliar analysis in long-term environmental monitoring programs. USEPA, Office of Research and Development, EPA/600/R-95/077

Silveira MLA, Alloni LRF, Guilherme LRG (2003) Biosolids and heavy metals in soils. Sci Agric 60:793-806

Sinegani AAS, Khalilikhah F (2011) The effect of application time of mobilising agents on growth and phytoextraction of lead by Brassica napus from a calcareous mine soil. Environ Chem Lett 9:259-265. doi:10.1007/s10311-010-0275-1

Skoog DA, West DM, Holler FL (1996) Fundamentals of analytical chemistry, 7th edn. Saunders College Publishing, Orlando, FL

Turan M, Esringü A (2007) Phytoremediation based on canol a (Brassica napus L.) and Indian mustard (Brassica juncea L.) planted on spiked soi by aliquot amount of $\mathrm{Cd}, \mathrm{Cu}, \mathrm{Pb}$, and $\mathrm{Zn}$. Plant Soil Environ 53:7-15

Turgut C, Babahan I, Atatanir L, Cutright TJ (2010) Assessment of two new ligands for increasing the uptake of $\mathrm{Cd}, \mathrm{Cr}$, and $\mathrm{Ni}$ in Helianthus annuus grown in a sandy-loam soil. Water Air Soil Pollut 210:289-295. doi:10.1007/s11270-009-0250-2

USEPA (1992) Technical support document for land application of sewage sludge, vol I and II (PB93-110575). Office of Water, Washington, DC

USEPA (1995) Laboratory methods for soil and foliar analysis in long-term environmental monitoring programs. EPA/600/R-95/ 077, United States Environmental Protection Agency, Office of Research and Development, Cincinnati

USEPA (2000) Introduction to phytoremediation. EPA 600/R-99/107, United States Environmental Protection Agency, Office of Research and Development, Washington, DC

Vogeler I, Green SR, Clothier BE, Kirkham MB, Robinson BH (2001) Contaminant transport in the root zone. In: Iskandar IK, Kirkham MB (eds) Trace elements in soils: bioavailability, flux, and transfer. Lewis Publishers, CRC Press, New York, pp 175-197

Wei JL, Lai HY, Chen ZS (2012) Chelator effects on bioconcentration and translocation of cadmium by hyperaccumulators, Tagetes patula and Impatiens walleriana. Ecotoxicol Environ Saf 84:173-178

Wua LH, Luo YM, Christie P, Wong MH (2003) Effects of EDTA and low molecular weight organic acids on soil solution properties of a heavy metal polluted soil. Chemosphere 50:819-822

Yeh TY, Pan CT (2012) Effect of chelating agents on copper, zinc uptake by sunflower, Chinese cabbage, cattail, and reed for different organic contents of soils. J Bioanal Biomed 4:6-10. doi: $10.4172 / 1948-593 X .1000056$

Zehra SS, Arshad M, Mahmood T, Waheed A (2009) Assessment of heavy metal accumulation and their translocation in plant species. Afr J Biotechnol 8:2802-2810 